\title{
Perceptions Of Corruption In Central Asian Countries
}

Brenda Swartz, (Email: bswartz@ius.edu), Indiana University Southeast Frank Wadsworth, (Email: fwadswo@ius.edu), Indiana University Southeast Jerry Wheat, (Email: jwheat@ius.edu), Indiana University Southeast

\begin{abstract}
Property rights are a basic tenant of a free market economy, and when these rights are in jeopardy from crime and corruption, a free market system falters. The European Bank for Reconstruction and Development (EBRD) and the World Bank have developed a methodology to study transition economies. The Business Environment and Enterprise Performance Survey (BEEPS II 2002) has gathered on a variety of topics from 23 transition economies. This paper uses the BEEPS data to examine the perceptions of Corruption and State Capture in Kazakhstan, Kyrgyzstan, Tajikistan, and Uzbekistan.
\end{abstract}

\section{INTRODUCTION}

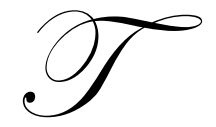

he breakup of the former Soviet Union created 16 independent countries. Those countries and the Eastern European countries that were under Soviet influence have in various stages moved away from a command economy and toward market economies. One of the economic activities that impeded the movement toward capitalism has been the encroaching "grey" economy which has long cast an expanding shadow on the transitioning economies. Other "off the books" economic activities were widespread in the former Soviet Republics. In the transition years uncertainty in some countries has created an opportunity for the gray economy to expand.

Corruption, which was also widespread during the Soviet era, took several forms, but manifest itself differently in what were then the Soviet client states. For example, in some states the government captured industries with severe regulations and individuals in the government were able to extract economic rent from the industry. In other states industries captured government (Parliaments for example) and were able with "gifts" to obtain favorable laws and regulations. State capture works because the industry is important to the state (or powerful individuals) or vise versa. Other examples include "gifts" to individual government employees to ignore laws and regulations. These gifts are called "grease the wheels of commerce" payments. This study examines the differences in the evolving economies of Kazakhstan, Uzbekistan, Tajikistan, and Kyrgyzstan utilizing World Bank data from the Business Environment and Enterprise Performance Survey (BEEPS).

The purpose of this study is to examine the World Bank data about corruption and the "grey" economy in the former Soviet states in Central Asia (Kazakhstan, Uzbekistan, Tajikistan, and Kyrgyzstan). The study results can be used by non-governmental organizations (NGO), government, and regulatory officials as a basis for making policy decision.

The World Bank in 1996 changed directions in its thinking about corruption. Prior to 1996 the World Bank tolerated corruption because they believed that corruption was the "grease that made the wheels of commerce" turn. James Wolfensohn, President of the World Bank, in a speech in 1996 declared that the World Bank policy in the future would be to assume that corruption was "sand in the wheels of commerce" and impeded economic growth. Accordingly, the World Bank asserted that they would no longer tolerate corruption. The United States in 1974 passed the Foreign Corruption Practice Act which subscribed to similar views. After 1996 individual EU countries passed similar legislation to the U.S.'s Foreign Corruption Practice Act. 


\section{OVER VIEW OF THE FOUR COUNTRIES}

The four Central Asian countries share many common features: they are former parts of the Soviet Union and they are all landlocked. Kazakhstan and Uzbekistan share the Aral Sea whose water levels are dropping because of increased irrigation. Chemical residue has dried and become an air-borne health hazard to area populations. Kyrgyzstan and Tajikistan have high mountains and surface transportation is problematic. Kyrgyzstan produces and exports hydro power. All of the four countries either produce cannabis and opium poppy or are part of the illegal Afghan trade route to Russia or Western Europe.

\begin{tabular}{|c|c|c|c|c|}
\hline & Kazakhstan & Kyrgyzstan & Tajikistan & Uzbekistan \\
\hline Size & 4 times size Texas & $\begin{array}{c}\text { Similar to South } \\
\text { Dakota }\end{array}$ & $\begin{array}{c}\text { Smaller than } \\
\text { Wisconsin }\end{array}$ & Similar to California \\
\hline Population 1 & 15 million & 5 million & 7 million & 27 million \\
\hline Median Age & 28.8 years & 23.6 years & 20 years & 22.7 years \\
\hline $\begin{array}{c}\text { Infant Mortality per } \\
1,000 \text { births } 2 \\
\end{array}$ & 28.3 & 34.5 & 106 & 70 \\
\hline GDP real growth rate 2 & $8.5 \%$ & $2 \%$ & $7 \%$ & $6.8 \%$ \\
\hline GDP per capita ppp 2 & $\$ 9,100$ & $\$ 2,000$ & $\$ 1,300$ & $\$ 2,000$ \\
\hline $\begin{array}{c}\text { Population Below } \\
\text { Poverty Line } 3\end{array}$ & $19 \%$ & $40 \%$ & $64 \%$ & $28 \%$ \\
\hline Inflation Rate 2 & $8.6 \%$ & $6.4 \%$ & $7.5 \%$ & $7.6 \%$ \\
\hline Unemployment Rate & $7.4 \% 3$ & $18 \% 3$ & $12 \% 3$ & $\begin{array}{c}.8 \% \text { plus another } 20 \% \\
\text { underemployed } 2\end{array}$ \\
\hline
\end{tabular}

Source: CIA World Factbook, February, 2007

1 July 2006 estimate

22006 estimate

32004 estimate

\section{THE BEEPS DATA BASE}

The European Bank for Reconstruction and Development (EBRD) and the World Bank (WB) have developed a methodology for studying the performance of transition economies such as the new EU entrants. The Business Environment and Enterprise Performance Survey (BEEPS II 2002) was developed to capture a wide variety of data from firms in countries undergoing political and economic transition. Data was collected on numerous aspects of business performance including sources of financing, corruption and business relationships with government. The study explored data from the major category Corruption and State Capture. Subcategories chosen from the data set were Public Procurement Kickbacks, State Capture, Tax Compliance, and Unoffical Payments. For a more detailed explanation of the BEEPS data base please visit the World Bank Institute at www.wbi.org.

\section{CORRUPTION AND STATE CAPTURE-PUBLIC PROCUREMENT KICKBACKS}

Examining the BEEPS category on "Corruption and State Capture" the subcategory on "Public Procurement Kickbacks" revealed some differences among the countries. Managers responded to the query: How much of the original contract value would be typically paid in additional or unofficial payments/gifts to secure the contract? Managers in Uzbekistan, Kazakhstan, and Tajikistan indicated that a typical unofficial payment would be of a lesser percentage of the contract price than did managers in Kyrgyzstan. (Mention \% groups?) Table ONE here

Table 1 - Public Procurement Kickbacks

\begin{tabular}{|c|c|c|}
\hline Question & Sig. & (3.1) \\
\hline $\begin{array}{c}\text { How much of original contract would be } \\
\text { additional payments or gifts to secure contracts }\end{array}$ & $\begin{array}{c}\text { Uzbekistan (3.0) }{ }^{\mathrm{A}} \text { and Kazakhstan (3.1) and Tajikistan (3.1) } \\
\text { < Kyrgytan (3.7) }\end{array}$ & .010 \\
\hline
\end{tabular}

${ }^{\mathrm{A}}$ Number in parentheses represent percent of original contract represented by additional payment 


\section{CORRUPTION AND STATE CAPTURE-STATE CAPTURE}

In the subcategory exploring private payments to public officials to gain favor, managers were asked about private payments (private payment/gifts or other benefits) to Parliamentarians to affect their votes. Managers in Kazakhstan, Tajikistan and Uzbekistan indicated that payments to parliamentarians had a lesser impact on voting than did managers in Kyrgyzstan. Likewise, in exploring the impact of these payments to government officials to affect the content of government decrees, managers indicated such payments in Kazakhstan had less impact than did managers in Kyrgyzstan, Uzbekistan, and Tajikistan.

A similar question was asked about the impact of private payments to judges to affect decisions of criminal court cases. Managers in Kazakhstan indicated private payments to judges were less likely to impact decisions in criminal cases than were private payments in Kyrgyzstan, Uzbekistan. Private payments to judges to affect criminal court cases had the most impact in Tajikistan.

Firms were asked about the impact of private payments to judges to affect the decisions in commercial cases. Managers indicated that in Kazakhstan private payments to judges were much less likely to influence commercial cases than were similar private payments made to judges in Uzbekistan and Kyrgyzstan. Firms indicated private payments to judges in Tajikistan were much more likely to impact commercial cases than the other three countries.

Firms were asked about private payments to central bank officials to affect bank policies and decision(s). Kazakhstan and Kyrgyzstan managers indicated private payments to central bank officials were much less likely to impact bank policies and decisions than did managers in Uzbekistan and Tajikistan.

Firms were asked about the impact of illegal contributions to political parties and/or election campaigns to affect the decisions of elected officials. Illegal payments of this type in Kazakhstan were deemed to have much less impact than were payments to political parties in Kyrgyzstan and Uzbekistan.

Table 2 - State Capture

\begin{tabular}{|c|c|c|}
\hline Question & & Sig. \\
\hline $\begin{array}{l}\text { Private payments or gifts to parliament to affect } \\
\text { their votes contracts }\end{array}$ & $\begin{array}{c}\text { Kazakhstan }(4.9)^{\mathrm{B}} \text { and Tajikistan (6.3) and Uzbekistan }(8.4)< \\
\text { Kyrgyzstan (12.8) }\end{array}$ & .001 \\
\hline $\begin{array}{l}\text { Private payments or gifts to government to affect } \\
\text { the content of government decrees }\end{array}$ & $\begin{array}{c}\text { Kazakhstan (4.2) < Kyrgyzstan (11.8) and Uzbekistan (12.1) and } \\
\text { Tajikistan (12.4) }\end{array}$ & .000 \\
\hline $\begin{array}{l}\text { Private payments or gifts to judges to affect the } \\
\text { decisions of criminal court cases }\end{array}$ & $\begin{array}{c}\text { Kazakhstan (4.4) }<\text { Kyrgyzstan (11.4) and Uzbekistan (11.7) < } \\
\text { Tajikistan (22.3) }\end{array}$ & .000 \\
\hline $\begin{array}{l}\text { Private payments or gifts to judges to affect the } \\
\text { decisions in commercial cases }\end{array}$ & $\begin{array}{c}\text { Kazakhstan (6.2) < Uzbekistan (13.0) and Kyrgyzstan (16.7) < } \\
\text { Tajikistan (26.3) }\end{array}$ & .000 \\
\hline $\begin{array}{l}\text { Private payments or gifts to central bank officials } \\
\text { to affect central bank policies and decisions }\end{array}$ & $\begin{array}{c}\text { Kazakhstan (3.7) and Kyrgyzstan (7.5) < Uzbekistan (14.2) and } \\
\text { Tajikistan (18.5) }\end{array}$ & .000 \\
\hline $\begin{array}{l}\text { Private payments or gifts to political parties to } \\
\text { affect the decisions of elected officials }\end{array}$ & Kazakhstan (2.6) < Kyrgyzstan (6.5) and Uzbekistan (7.7) & .007 \\
\hline
\end{tabular}

\section{CORRUPTION AND STATE CAPTURE-TAX COMPLIANCE}

The BEEPS survey also asked managers: "Recognizing the difficulties that many firms face in fully complying with taxes and regulations what per cent of total annual sales would you estimate the typical firm in your area of business reports for tax purposes?" Firms in Tajikistan and Kyrgyzstan report a lower percent of annual sales for tax purposes than do firms in Kazakhstan. Firms in Uzbekistan report the greatest percentage of annual sales for tax purposes. 
Table 3 - Tax Compliance

\begin{tabular}{|c|c|c|}
\hline Question & Sig. \\
\hline $\begin{array}{c}\text { Percent of total annual sales firms in your business } \\
\text { report for tax purposes }\end{array}$ & $\begin{array}{c}\text { Tajikistan }(68.4)^{\mathrm{C}} \text { and Kyrgyzstan }(69.3)<\text { Kazakhstan }(78.0) \\
<\text { Uzbekistan }(84.4)\end{array}$ & .000 \\
\hline
\end{tabular}

\section{CORRUPTION AND STATE CAPTURE-UNOFFICIAL PAYMENTS}

Firms were asked to comment about the frequency of unofficial (irregular/additional payments/gifts) to get things done e.g. customs, licenses, regulations, services, etc. Firms in Uzbekistan make unoffical payments less frequently than do firms in Kazakhstan and Tajikistan. Firms in Kyrgyzstan make these types of payments more frequently than do firms in the other three countries.

Firms were queried about whether it was common for firms in their industry to know in advance about how much the unoffical payment would be. Uzbek firms were much less likely to know in advance the size of the unoffical payment than were firms in Kazakhstan and it Tajikistan. Firms in Kyrgyzstan were most likely to know the amount of expected payment.

Firms were asked about the percent of total annual sales firms like theirs typically pay in unofficial payments/gifts to public officials. Firms in Uzbekistan, Tajikistan, and Kazakhstan typically pay a smaller percentage of annual sales to public officials than do firms in Kyrgyzstan. While the difference is significant, the average percentage paid for all four countries was less than $4.5 \%$.

Table 4 - Unofficial Payments

\begin{tabular}{|c|c|c|}
\hline Question & & Sig. \\
\hline $\begin{array}{l}\text { Common for firms to have to make some irregular } \\
\text { payment or gifts with regard to customs, taxes, } \\
\text { licenses, regulations, services, etc. }\end{array}$ & 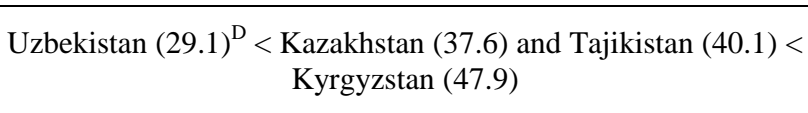 & .000 \\
\hline $\begin{array}{l}\text { Common for firms to know in advance about how } \\
\text { the size of this irregular payment or gift }\end{array}$ & $\begin{array}{c}\text { Uzbekistan }(28.2)^{\mathrm{E}}<\text { Kazakhstan (36.9) and Tajikistan (39.4) }< \\
\text { Kyrgyzstan (45.5) }\end{array}$ & .000 \\
\hline $\begin{array}{c}\text { Percent of total annual sales firms in your business } \\
\text { pay in unofficial payments or gifts to public } \\
\text { officials }\end{array}$ & $\begin{array}{c}\text { Uzbekistan (3.0) }{ }^{\mathrm{F}} \text { and Tajikistan (3.1) and Kazakhstan (3.3) < } \\
\text { Kyrgyzstan (4.4) }\end{array}$ & \\
\hline
\end{tabular}

\section{CORRUPTION AND STATE CAPTURE--FREQUENCY OF UNOFFICIAL PAYMENTS}

Respondents were asked about how often firms like theirs would make unofficial payments to get connected to and maintain public services (electricity and telephone). Firms in Uzbekistan and Kazakhstan made such payments less often than did firms in Kyrgyzstan. Firms in Tajikistan made these payments more often that did firms in the other three countries.

Firms were asked about how often they would make unofficial payments to officials to obtain business licenses and permits. Firms in Uzbekistan made these payments less frequently than did firms in Kyrgyzstan and Tajikistan. A similar question was asked about the frequency of unofficial payments to obtain government contracts. Firms in Uzbekistan and Kazakhstan paid these unofficial payments less frequently than did firms in Tajikistan and Kyrgyzstan. 
Firms were asked about how often firms like theirs would make unofficial payments to deal with occupational health and safety inspections. Firms in Uzbekistan made these unofficial payments less frequently than did firms in Tajikistan and Kyrgyzstan. Queried about unofficial payments to deal with firm and building inspections firms in Uzbekistan and Kazakhstan indicated they made these types of payments less frequently than did respondents in Tajikistan and Kyrgyzstan.

Firms were asked about how often firms like theirs would make unofficial payments to deal with environmental inspections. Uzbekistan and Kazakhstan made these unofficial payments less frequently than did firms in Kyrgyzstan. Firms in Tajikistan more frequently made these types of payments than did firms in the other three countries.

Firms were asked about how often firms like theirs would make unofficial payments to deal with taxes and tax collection. Firms in Kazakhstan and Uzbekistan made these types of unofficial payments less frequently than did firms in Tajikistan and Kyrgyzstan. When asked about the frequency of unofficial payments to deal with customs/imports, Uzbek and Kazak firms used this route less frequently than did firms in Kyrgyzstan. Firms in Tajikistan used this type of unofficial payment more frequently than did firms in the other three countries.

Firms in Uzbekistan and Kazakhstan used unofficial payments to deal with courts and to impact the content of new legislation rules less frequently that did firms in Kyrgyzstan and Tajikistan.

Table 5 - Frequency of Unofficial Payments

\begin{tabular}{|c|c|c|}
\hline Question & & Sig. \\
\hline $\begin{array}{c}\text { How often do firms make payments or gifts to get } \\
\text { connected to and maintain public services } \\
\text { (electricity and telephone) }\end{array}$ & $\begin{array}{c}\text { Uzbekistan }(17.4)^{\mathrm{G}} \text { and Kazakhstan }(20.8)<\text { Kyrgyzstan }(27.0) \\
<\text { Tajikistan }(37.9)\end{array}$ & .000 \\
\hline $\begin{array}{l}\text { How often do firms make payments or gifts to } \\
\text { obtain business licenses and permits }\end{array}$ & Uzbekistan (12.6) < Kyrgyzstan (19.6) and Tajikistan (23.8) & .001 \\
\hline $\begin{array}{l}\text { How often do firms make payments or gifts to } \\
\text { obtain government contracts }\end{array}$ & $\begin{array}{c}\text { Uzbekistan (7.8) and Kazakhstan (8.4) < Tajikistan (12.2) and } \\
\text { Kyrgyzstan (11.4) }\end{array}$ & .000 \\
\hline $\begin{array}{l}\text { How often do firms make payments or gifts to deal } \\
\text { with occupational health and safety inspections }\end{array}$ & Uzbekistan (13.6) < Tajikistan (21.9) and Kyrgyzstan (24.3) & .000 \\
\hline $\begin{array}{l}\text { How often do firms make payments or gifts to deal } \\
\text { with fire and building inspections }\end{array}$ & $\begin{array}{c}\text { Uzbekistan (8.9) and Kazakhstan (10.7) < Tajikistan (19.4) and } \\
\text { Kyrgyzstan (21.6) }\end{array}$ & .000 \\
\hline $\begin{array}{l}\text { How often do firms make payments or gifts to deal } \\
\text { with environmental inspections }\end{array}$ & $\begin{array}{c}\text { Uzbekistan (7.9) and Kazakhstan (9.5) < Kyrgyzstan }(15.4)< \\
\text { Tajikistan }(26.5)\end{array}$ & .000 \\
\hline $\begin{array}{l}\text { How often do firms make payments or gifts to deal } \\
\text { with taxes and tax collections }\end{array}$ & $\begin{array}{c}\text { Uzbekistan (22.0) and Kazakhstan (24.6) < Kyrgyzstan (45.0) < } \\
\text { Tajikistan (49.4) }\end{array}$ & .000 \\
\hline $\begin{array}{l}\text { How often do firms make payments or gifts to deal } \\
\text { with customs/imports }\end{array}$ & $\begin{array}{c}\text { Uzbekistan (12.4) and Kazakhstan (15.2) < Kyrgyzstan (22.8) < } \\
\text { Tajikistan (30.1) }\end{array}$ & .000 \\
\hline $\begin{array}{l}\text { How often do firms make payments or gifts to deal } \\
\text { with courts }\end{array}$ & $\begin{array}{c}\text { Uzbekistan (8.3) and Kazakhstan (8.8) < Kyrgyzstan (19.4) and } \\
\text { Tajikistan (24.1) }\end{array}$ & .000 \\
\hline $\begin{array}{l}\text { How often do firms make payments or gifts to deal } \\
\text { with the content of new legislation rules, decrees, } \\
\text { etc. }\end{array}$ & $\begin{array}{c}\text { Uzbekistan (4.3) and Kazakhstan (4.9) < Kyrgyzstan (11.8) and } \\
\text { Tajikistan (12.1) }\end{array}$ & .000 \\
\hline
\end{tabular}




\section{PERCEPTIONS OF THE BUSINESS ENVIRONMENT}

Firms were asked to assess how problematic various factors were for the operation and growth of their business. Firms in Kazakhstan had less problems accessing financing than did firms in Kyrgyzstan, Uzbekistan, and Tajikistan. Firms in Kazakhstan, Uzbekistan, and Kyrgyzstan had fewer problems with the cost of financing than did firms in Tajikistan.

Firms in Kazakhstan had fewer problems with telecommunications than did firms in Kyrgyzstan and Tajikistan. Firms in Kazakhstan and Uzbekistan had fewer problems with electricity than did firms in Kyrgyzstan. Firms in Tajikistan had greater difficulties with electricity than did firms in the other three countries.

Firms in Kazakhstan, Kyrgyzstan and Uzbekistan had fewer transportation impediments than did firms in Tajikistan. Firms in Kazakhstan saw access to land an impediment to operations and growth less of a problem than did firms in Tajikistan.

Firms in Kazakhstan indicated that tax rates and tax administration were less problematic to the operation and growth of business than did firms in Kyrgyzstan and Tajikistan. Firms in Kazakhstan, Kyrgyzstan, and Uzbekistan found customs and trade regulation less problematic than did firms in Tajikistan. Firms in Uzbekistan, Kazakhstan, and Kyrgyzstan found business licensing and permits less of a problem than did firms in Tajikistan.

Labor regulations posed less of a problem for firms in Uzbekistan and Kazakhstan than did labor regulations in Tajikistan. Firms in Uzbekistan indicated that the level of skills and education of available workers was less of a problem than did firms in Kyrgyzstan.

Firms in Kazakhstan felt that economic policy uncertainty was less of a problem for the operation and growth of their business than did firms in Tajikistan. Firms in Kazakhstan were felt macroeconomic instability (inflation, exchange rates) were less problematic for the operation and growth of their businesses than did firms in the other three countries.

Firms in Uzbekistan and Kazakhstan felt the functioning of the judiciary was less problematic to the operation and growth of their businesses than did firms in Kyrgyzstan. Firms in Uzbekistan found corruption less problematic than did firms in Kazakhstan. Firms in Tajikistan and Kyrgyzstan found corruption more problematic than did firms in the other two countries.

Street crime, theft, or disorder appeared to be less of a problem for firms in Uzbekistan and Tajikistan than for firms in Kazakhstan. Firms in Kyrgyzstan found street crime, theft, or disorder more problematic than did firms in the other countries. Organized crime or Mafia intrusion was deemed less problematic by firms in Uzbekistan than by firms in Kazakhstan. Firms in Tajikistan and Kyrgyzstan felt organized crime or the Mafia influence more problematic.

Anticompetitive practices were less problematic for firms in Uzbekistan than for firms in Kazakhstan, Kyrgyzstan, and Tajikistan. Contract violations by customers or suppliers were less problematic for firms in Kazakhstan, Uzbekistan, and Kyrgyzstan than they were for firms in Tajikistan. Title or leasing of land were deemed less problematic for firms in Kazakhstan and Uzbekistan than for firms in Tajikistan and Kyrgyzstan. 
Table 6 - Perceptions of the Business Environment

\begin{tabular}{|c|c|c|}
\hline Question & & Sig. \\
\hline $\begin{array}{l}\text { How problematic is access to financing for the } \\
\text { operation and growth of your business }\end{array}$ & Kazakhstan $(24.9)^{\mathrm{H}}<$ Kyrgyzstan $(30.1)<$ Tajikistan $(40.5)$ & .000 \\
\hline $\begin{array}{l}\text { How problematic is the cost of financing for the } \\
\text { operation and growth of your business }\end{array}$ & $\begin{array}{c}\text { Kazakhstan (29.0) and Uzbekistan (34.9) and Kyrgyzstan (35.0) } \\
\text { < Tajikistan (42.2) }\end{array}$ & .000 \\
\hline $\begin{array}{l}\text { How problematic is telecommunications for the } \\
\text { operation and growth of your business }\end{array}$ & Kazakhstan (7.7) < Kyrgyzstan $(13.1)<$ Tajikistan $(19.2)$ & .000 \\
\hline $\begin{array}{l}\text { How problematic is electricity for the operation } \\
\text { and growth of your business }\end{array}$ & $\begin{array}{c}\text { Kazakhstan (8.1) and Uzbekistan }(11.6)<\text { Kyrgyzstan }(16.2)< \\
\text { Tajikistan }(29.1)\end{array}$ & .000 \\
\hline $\begin{array}{l}\text { How problematic is transportation for the } \\
\text { operation and growth of your business }\end{array}$ & $\begin{array}{c}\text { Kazakhstan (9.1) and Kyrgyzstan (11.2) and Uzbekistan (11.2) } \\
\text { < Tajikistan (19.6) }\end{array}$ & .000 \\
\hline $\begin{array}{l}\text { How problematic is access to land for the } \\
\text { operation and growth of your business }\end{array}$ & Kazakhstan $(10.1)<$ Tajikistan $(17.2)$ & .009 \\
\hline $\begin{array}{l}\text { How problematic is tax rates for the operation } \\
\text { and growth of your business }\end{array}$ & Kazakhstan $(32.4)<$ Kyrgyzstan $(38.7)<$ Tajikistan (44.3) & .000 \\
\hline $\begin{array}{l}\text { How problematic is tax administration for the } \\
\text { operation and growth of your business }\end{array}$ & Kazakhstan (33.9) < Kyrgyzstan (40.2) < Tajikistan (42.7) & .007 \\
\hline $\begin{array}{l}\text { How problematic is customs and trade } \\
\text { regulations for the operation and growth of your } \\
\text { business }\end{array}$ & $\begin{array}{c}\text { Kazakhstan (20.7) and Kyrgyzstan (22.3) and Uzbekistan (24.4) } \\
\text { < Tajikistan (31.4) }\end{array}$ & .002 \\
\hline $\begin{array}{c}\text { How problematic is business licensing and } \\
\text { permits for the operation and growth of your } \\
\text { business }\end{array}$ & $\begin{array}{c}\text { Uzbekistan (18.7) and Kazakhstan (20.3) < Kyrgyzstan (22.4) } \\
\text { and Tajikistan (32.3) }\end{array}$ & .000 \\
\hline $\begin{array}{l}\text { How problematic is labor regulations for the } \\
\text { operation and growth of your business }\end{array}$ & Uzbekistan (7.2) and Kazakhstan (7.6) < Tajikistan (11.7) & .028 \\
\hline $\begin{array}{l}\text { How problematic is skills and education of } \\
\text { available workers for the operation and growth of } \\
\text { your business }\end{array}$ & Uzbekistan $(14.6)<$ Kyrgyzstan $(21.1)$ & .009 \\
\hline $\begin{array}{l}\text { How problematic is economic policy uncertainty } \\
\text { for the operation and growth of your business }\end{array}$ & Kazakhstan $(31.5)<$ Uzbekistan $(37.3)<$ Tajikistan $(43.9)$ & .000 \\
\hline $\begin{array}{l}\text { How problematic is macroeconomic instability } \\
\text { (inflation, exchange rates) for the operation and } \\
\text { growth of your business }\end{array}$ & $\begin{array}{c}\text { Kazakhstan (30.8) }<\text { Kyrgyzstan (42.3) and Uzbekistan (45.3) } \\
\text { and Tajikistan (45.7) }\end{array}$ & .000 \\
\hline $\begin{array}{l}\text { How problematic is functioning of the judiciary } \\
\text { for the operation and growth of your business }\end{array}$ & Uzbekistan (16.7) and Kazakhstan (16.7) < Kyrgyzstan (24.4) & .002 \\
\hline $\begin{array}{l}\text { How problematic is corruption for the operation } \\
\text { and growth of your business }\end{array}$ & $\begin{array}{c}\text { Uzbekistan }(17.7)<\text { Kazakhstan }(24.8)<\text { Tajikistan (31.7) and } \\
\text { Kyrgyzstan }(33.7)\end{array}$ & .000 \\
\hline $\begin{array}{c}\text { How problematic is street crime or theft or } \\
\text { disorder for the operation and growth of your } \\
\text { business }\end{array}$ & $\begin{array}{c}\text { Uzbekistan (14.5) and Tajikistan }(14.8)<\text { Kazakhstan }(20.2)< \\
\text { Kyrgyzstan }(29.1)\end{array}$ & .000 \\
\hline $\begin{array}{l}\text { How problematic is organized crime or Mafia for } \\
\text { the operation and growth of your business }\end{array}$ & $\begin{array}{c}\text { Uzbekistan }(11.2)<\text { Kazakhstan }(16.4)<\text { Tajikistan }(22.1) \text { and } \\
\text { Kyrgyzstan }(25.2)\end{array}$ & .000 \\
\hline $\begin{array}{c}\text { How problematic is anticompetitive practices of } \\
\text { other producers for the operation and growth of } \\
\text { your business }\end{array}$ & $\begin{aligned} \text { Uzbekistan (14.8) < } & \text { Kazakhstan (21.1) and Kyrgyzstan (25.3) } \\
& \text { and Tajikistan (26.7) }\end{aligned}$ & .000 \\
\hline $\begin{array}{l}\text { How problematic is contract violations of or by } \\
\text { customers and suppliers for the operation and } \\
\text { growth of your business }\end{array}$ & $\begin{array}{c}\text { Kazakhstan (22.4) and Uzbekistan (22.6) and Kyrgyzstan (27.8) } \\
\text { < Tajikistan (33.0) }\end{array}$ & .000 \\
\hline $\begin{array}{l}\text { How problematic is title or leasing of land for the } \\
\text { operation and growth of your business }\end{array}$ & $\begin{array}{c}\text { Kazakhstan (10.5) and Uzbekistan (10.8) < Tajikistan (17.0) and } \\
\text { Kyrgyzstan (20.5) }\end{array}$ & .000 \\
\hline
\end{tabular}




\section{CONCLUSION}

Several patterns emerge from the data. In general it appears that Kazakhstan and Uzbekistan are perceived to be less corrupt than Tajikistan and Kyrgyzstan. In some cases Kazakhstan is perceived to be the least corrupt and in others Uzbekistan is thought to be less corrupt. Perceptions of Tajikistan as more corrupt are prevalent but in some situations Kyrgyzstan is considered more corrupt.

\section{REFERENCES}

1. $\quad$ www.wbi.org World Bank Institute Data Base

2. www.worldbank.org/wbi/governance/pdf/wei.pdf Statement similar to the one made by James

Wolfensohn, President of the World Bank, Transition, 7(9-10), p9, September/October 1996.

\section{NOTES}

